This is the author's Post-print version (final draft post-refereeing as accepted for publication by the journal). The definitive, peer-reviewed and edited version of this article is published as: Helderman A., van Ham M. and Mulder C.H. (2006) Migration and homeownership. Journal of Economic and Social Geography (TESG) 97(2), 107-121. http://dx.doi.org/10.1111/j.1467-9663.2006.00506.x

\title{
MIGRATION AND HOME OWNERSHIP
}

\author{
AMANDA C. HELDERMAN*, MAARTEN VAN HAM** and CLARA H. \\ $\operatorname{MULDER} * * *$ \\ University of Amsterdam, Department of Geography and Planning, Amsterdam \\ institute for Metropolitan and International Development Studies (AMIDSt), Nieuwe \\ Prinsengracht 130, $1018 \mathrm{VZ}$ Amsterdam, The Netherlands, fax +3120 5254051, e- \\ mail:*a.c.helderman@uva.nl, ***c.h.mulder@uva.nl \\ ** Utrecht University, Faculty of Geosciences, Urban and Regional research \\ centre Utrecht (URU), P.O. Box 80.115, 3508 TC, The Netherlands, Fax +31 30253 \\ 2037,e-mail: m.vanham@geog.uu.nl
}

\begin{abstract}
It is well known that home ownership has an impeding effect on migration. However, the strong increase in home ownership in the Netherlands since the Second World War has not led to a decrease in migration. In this paper three factors are identified which might have counterbalanced the expected negative effect of increasing home ownership on migration. First, the composition of the population of homeowners has changed in the direction of younger, more mobile households. Second, home ownership has become more common, possibly leading to greater dynamics within the owner-occupied segment of the housing market. And third, macro factors such as economic growth might have led to more migration. Using the Housing Demand Surveys and logistic regression analysis, we investigated to what extent the effect of home ownership on migration changed in the Netherlands in the 1980s and 1990s. We find - contrary to what we expected - that during the research period the negative effect of home ownership on migration seems to have strengthened somewhat. Within the research period, however, this negative effect was compensated by a general rise in migration for both owning and renting households, possibly attributable to macro factors affecting migration, such as economic growth and changes on the housing market.
\end{abstract}

Key words: home ownership, migration, housing market, logistic regression analysis, the Netherlands

\section{INTRODUCTION}

Migration - changing residence over long distances - is an important instrument enabling people to improve their earnings and labour market position. Workers who are prepared to accept jobs over a longer distance and change residence can take 
advantage of job opportunities elsewhere. Migrants tend to earn more after a move than before (Bartel 1979; Davanzo 1981; Haapanen 2003; Sjaastad 1962; Smits 2001). It is important for individuals to be flexible so that they can take full advantage of opportunities offered on the labour market (Van Ham, 2002). On the macro-level, a lack of spatial flexibility of the workforce might have negative consequences because the available national human capital is under-utilised. A lack of spatial flexibility might also cause workers to decide to commute over longer distances with longer commuting trips as a result (Van Ommeren et al. 2000; Yapa et al. 1971). This leads to more pressure on infrastructure, leading to road congestion, and possible environmental problems (Schutjens et al. 1998).

People do not generally take the decision to migrate lightly. There are many ties connecting a person to a certain location; one of the main barriers to migration is home ownership. It has often been found that home ownership has a negative effect on migration (Clark \& Dieleman 1996; Speare et al. 1975; Van Leuvensteijn \& Koning 2000). The main reason put forward for this is that moving from an owneroccupied home is more costly than moving from a rented home, because of specific transaction costs.

Since the Second World War, home ownership in the Netherlands has increased strongly. In the 1980s and 1990s home ownership grew from 41 to 51 percent (Netherlands Ministry of Spatial Planning, Housing and the Environment 2002), partly because it has been stimulated by the Netherlands government by means of tax benefits. Because of the negative effect of home ownership on migration, the increase in home ownership could be expected to lead to a decrease in migration in the Netherlands.

Suprisingly, however, the increase in home ownership did not lead to a decrease in the overall migration levels; migration propensities have remained stable over the last two decades. Possible explanations for this surprising finding might be that the negative effect of home ownership was compensated by other factors, or that the negative effect may have changed over time. If the compensating effects are only temporary, there might be reason for concern, because migration levels, and therefore the spatial flexibility of the population, might be influenced negatively by the increased level of home ownership in the future. It is therefore important to investigate which compensating factors have been in play and whether their nature is temporary or not.

The above leads to the following research questions: To what extent did the effect of home ownership on migration changed in the Netherlands in the 1980s and 1990s? And which mechanisms counterbalancing the expected effect of the growth if home ownership on migration can be identified for this period? The Housing Demand Surveys of Statistics Netherlands, conducted from 1981 till 1998, and logistic regression analysis of having migrated recently before the surveys have been used to address these questions.

\section{THEORY AND BACKGROUND}

Migration behaviour; triggers, restrictions and opportunities - Events that can trigger migration are found in the different parallel life course careers (Mulder \& Hooimeijer 1999). Migration decisions originate most often in the occupational career or the educational career (Mulder 1993). People often need to migrate if they accept a 
job located beyond the commuting distance that can be covered within a reasonable travel time for sustaining a daily commute (Van Ham 2002; Van Ommeren 1996).

People will not generally migrate unless it is necessary to do so, because migration has many more consequences than merely moving a home. People who move over a long distance can no longer frequent the familiar nodes of services, friends, workplaces, and schools because they no longer live within a reasonable travel time. The area that is contained by this reasonable travel time from the place of residence is referred to as the potential daily activity space (Hägerstrand 1970; Roseman 1971). Displacing the daily activity space makes migration costly. Migration is therefore only undertaken if it is expected to render more than it costs.

In addition to triggers and restrictions, the presence (or lack) of opportunities on both the housing and the labour market also influences migration. The probability that people will migrate increases when jobs are available elsewhere that are better than the one currently held. At the same time, if it is difficult to find a home within alternative regional labour markets, the probability that people migrate decreases.

Home ownership and migration - Home ownership is known to have an impeding effect on moving behaviour (Clark \& Dieleman 1996; Helderman et al. 2004; Speare et al. 1975; Van Leuvensteijn \& Koning 2000). Owning a home can be seen as a specific local tie that can be described as location-specific capital or location-specific advantages (Bartel 1979; Davanzo 1981; Fischer \& Malmberg 2001). Because of these local ties, homeowners are less likely to migrate than renters are.

With an owner-occupied home comes a long-term financial commitment, mostly in the form of a mortgage. A large share of most homeowners' savings is tied up in their home, so moving is harder for homeowners than for renters. When they move, homeowners are confronted with higher transaction costs than renters are. The transaction costs involved in selling a home contain both financial and non-financial costs. There are moving costs, taxes to pay, and the services of an estate agent, as well as the effort involved in selling the home.

The implications of the specific transaction costs of moving to or from owneroccupied housing compared with rental housing are reinforced by a certain selectivity of home ownership. People who are expecting to move again soon do not usually buy a home. Stability in income and a stable relationship between partners or family members facilitate carrying the financial burden and are often also conditional for buying a home. Reasons for not (yet) buying a home may in many cases be related to not (yet) having reached a stable position on the labour market, or foreseeing an early move for housing or household reasons.

Home ownership grew from 41 percent to 51 percent in the Netherlands in the 1980s and 1990s (Netherlands Ministry of Spatial Planning, Housing and the Environment 2002). Underlying this growth are rising incomes - mainly from the increased number of dual-income households - and the continuation of government policy geared towards stimulating home ownership by tax benefits rather than through government support for rental housing. If the negative effect of home ownership on migration described above has not changed, one would expect the overall occurrence of migration to decrease, beacause of the growth of home ownership. This, however, has not been the case, so there must have been counterbalancing factors playing a part.

Several factors can be considered capable of counterbalancing the impeding effect of home ownership on migration, including changes in the composition of the population of homeowners in the direction of more mobile household types. Over the 
last few decades, the composition of the population of homeowners has shifted towards younger and childless households (Feijten \& Mulder 2002; Mulder \& Wagner 1998). The young and childless are often still shaping their labour market careers. They might be relatively more likely to migrate - even though they own a home than other categories of homeowners, especially families with children, who are also tied to their children's schools.

Second, the importance of home ownership as a restriction for migration might have decreased. While home ownership is increasing, the number of options in the owner-occupied segment of the housing market is growing. These provide more opportunities for improvement within this segment. Furthermore, becoming a homeowner is regarded to a lesser extent as an 'end-destination' in the housing career. Increasingly, households move within the owner-occupied segment, with every change of residence representing an upward step in the housing career.

Third, the influence of economic and other macro circumstances on migration can be expected to be considerable. There is a better chance for career advancement in times of economic prosperity (De Koning et al. 2003) possibly leading to more job changes and more migration. The improved housing market circumstances and the low mortgage interest rate in the late 1990s might also have played a part. Therefore, the negative effect of a growth in home ownership on migration might have been counterbalanced at the end of the 1990s. To make clear the implications of the changing composition of the population of homeowners, we must first pay some attention to the individual determinants of migration.

Individual determinants of migration - Migration is not equally likely for all. At earlier ages people are still in the process of gathering experience and developing a range of skills that are obtainable in different places. Many young people are not yet strongly committed to particular places to live, work, or spend leisure time, so that the potential daily activity space has a less permanent status. Furthermore, as people become older, they have fewer years of work ahead of them in which to recoup the costs of a move. The probability of migrating can therefore be expected to decrease with increasing age.

Well-paid jobs for which people need a high level of education are generally concentrated in a limited number of places (Börsch-Supan 1990; Simpson 1992; Van Ham 2002). Consequently, highly-educated people need a larger search area to find a better job and are thus more likely to move over greater distances (Mulder 1993; Van Ham et al. 2001). A high income furthermore allows people to afford the transaction costs involved with buying and selling a home. A higher income also brings a larger range of available housing options within the reach of the household income. Both of these reasons would lead us to expect the probability of migration to increase with increasing income.

The selfemployed often have less flexibility when locating their workplace than people who have an employer. The selfemployed are often tied to local investments and relationships with clients and suppliers which, like home ownership, can be defined as location-specific capital, or location-specific advantages (Fischer \& Malmberg 2001). Furthermore, selfemployed people are never subject to transfer. We can therefore expect selfemployment to have a negative effect on migration.

Dual-income households have to combine two workplaces with one residential location. In this situation, if one of the working partners wants to accept a job over a longer distance, there will also be implications for the other working partner. We therefore expect dual-income households to be less likely to move over larger 
distances than households with one income, other things being equal (see also Hardill et al. 1997; Smits et al. 2003; Van Ham 2002). The composition of households can also be expected to influence the probability of migration. People running a oneperson household are often more free to migrate, because they do not have to deal with multiple individual wishes if they decide that a move is necessary. Families with children can be expected to be the households least likely to migrate.

The changing composition of the population of homeowners - Homeowners are different from renters (Helderman 2004). Among homeowners there are more households with children, more dual earner households, and more high income households.

$<$ Please insert Table 1 about here $>$

As can be seen in Figure 1, over the past few decades the share among homeowners of one-person households and couples without children has increased. The young childless couples constitute the fastest growing group of home owning households (Helderman et al. 2004). These households also increasingly frequently have two incomes. Even though incomes have not risen as steadily as have house prices, acquiring a mortgage has become easier for these groups, because lenders have become more inclined to base the maximum mortgage amount on two incomes.

<Please insert Figure 1 about here>

As stated above, young people living in one-person households or as couples without children have a higher probability of migrating than couples with children. The development towards more mobile homeowners can be expected to decrease the selectivity of home ownership. With the advancement of more mobile households into home ownership, for the category of homeowners as a whole home ownership might have had a diminished effect on migration even if it stays the same for the separate household types. At the same time, the increase in dual earnership among homeowners might to some extent have offset the expected increase in migration of homeowners.

The potentially changing effect of home ownership on migration - In addition to changes in the composition of homeowners, a potentially important change in the meaning of home ownership may be expected to operate as a restriction to migration. An increased choice on the owner-occupied segment of the housing market and falling interest rates making new mortgages easier to obtain might have led to a greater ease of moving within this segment and more opportunities to improve one's housing situation within the owner-occupier market. As a result the owner-occupier market would acquire a different function, with homeowners still moving less than renters, but with more internal dynamics within the owner-occupied segment than before. First-time homeowners might regard their home less as the 'final destination' in the housing career than they used to. A move to an owner-occupied home might thus increasingly be a step in a series of moves to owner-occupied homes, with each step signifying a move upwards in the owner-occupied segment. These potentially changing internal dynamics in the owner-occupied segment of the housing market might have brought about a change in the importance of home ownership as a 
restriction for migration. This change might have helped diminish the negative effect of home ownership on migration.

Macro-level factors affecting migration - Economic growth has a strong positive effect on the number of job transitions (De Koning et al. 2003), and can therefore be expected to boost migration for reasons of job change, which is the most important reason for migration. An economic crisis, as was the case in 1992, results in fewer job changes and less frequent entrance into employment for non-participating people. Periods of economic growth and a restored labour market - as occurred from 1994 onwards - have greater job availability. The period from 1996 to 2000 showed a particularly marked increase in the number of job changes. At the end of the research period, migration - among both renters and owners - might well have been facilitated by the economic growth and increased prosperity in the Netherlands, possibly fostering a change in attitude towards the investment of home ownership and moving behaviour. This prosperity may also have helped counterbalance the negative effect of home ownership on migration.

The probability that people have of migrating can also be expected to vary over time as a result of changes on the housing market. This is susceptible to temporal change resulting from economic circumstances, household evolution, changes in new construction, or changes in the mortgage interest rate. The successive Housing Demand Surveys indicate that the housing shortage was at a historical low at the end of the 1990s. The opportunities for people to realise their migration wishes probably increased.

The spatial distribution of employment and housing opportunities is expected to have an influence on migration, because the tolerable commuting distance might not afford access to alternative regional markets. There are more specialised jobs available in urban areas than in rural (or less urbanised) areas. Migration to facilitate career advancement is therefore less necessary in urban areas (Van Ham 2002).

\section{DATA \& METHOD}

Three analytical steps are needed to investigate the role of these three causes: first, to investigate the evolution of total migration; second, to compare the evolution of the migration of homeowners with that of renters (that is, to investigate the changes in the effect of home ownership on migration); third, to investigate this effect after accounting for the individual determinants of migration.

The data used in this study originate from five Netherlands Housing Demand Surveys (WoningBehoefteOnderzoeken 1981; 1985-86; 1989-90; 1994 and 1998). Statistics Netherlands conducts this survey approximately every four years. The research population is representative of the Netherlands population aged 18 and over and not living in institutions. In the datasets, both individual and household characteristics can be found. The respondent is considered a reference person for the household. What makes the Housing Demand Survey particularly suitable for this study is the data on residential moves in the four years preceding the interview as well as information about the previous place of residence and the previous household situation.

Migration is defined as a residential move over a distance greater than 35 kilometres. Below 35 kilometres, people mainly move for housing reasons; above the 35 kilometres breakpoint, job reasons become predominant. Moves exceeding 35 
kilometres occur in approximately 68 percent of the cases for job reasons (see also Goetgeluk 1997). The time needed to travel 35 kilometres also approximates the general commuting tolerance, an equivalent of about 45 minutes (Van Ommeren 1996).

The analyses were restricted to respondents aged between 25 and 55 years and living in independent dwellings. People still living with their parents were excluded, because their housing tenure is in fact their parents' tenure. The lower age limit was chosen to exclude students. These are likely to migrate for enrolment into education, which is a different phenomenon from job-related moves, the main type of migration of interest here.

The research population consists of people who did not move in the two years preceding the interview and people who moved over a distance of more than 35 kilometres in that same period. Moving over a distance of 35 kilometres or less is regarded as a competing risk (compare Hachen 1988). Respondents who moved over a distance of less than 35 kilometres were therefore excluded from the analyses. The combined dataset contains 151,581 respondents $\left(\mathrm{N}_{1981}=33,069 ; \mathrm{N}_{1985-86}=27,116 ; \mathrm{N}_{1989}\right.$ $\left.{ }_{90}=27,832 ; \mathrm{N}_{1994}=32,541 ; \mathrm{N}_{1998}=31,023\right)$. Of these, about 1.3 percent $(1,970)$ had moved over a distance of more than 35 kilometres in the two years preceding the interview. Limiting the period in which people might have moved to the year of interview and the year preceding the interview allows values at the moment of interview to be used as a proxy for those at the moment of the potential move.

The first analytical step consists of a graphical representation of the evolution of migration for the total population and for several relevant sub-categories, including homeowners and renters. For this analysis, a different migration interval was used. Only one full year of observation - the one before the year of interview - has been used. The observation periods of the individual Housing Demand Surveys are slightly longer for some than for others owing to shifts in the months of interview. Particularly in 1998, a greater share of interviews was conducted at the end of the year or early in 1999.

The method used for the second analytical step was logistic regression analysis. The dependent variable describes whether or not migration occurred. Wherever possible, variables were measured just before the potential move. The net annual household income and education level were not measured before the potential move, but at the moment of interview. Table 2 presents the summary of the statistics and definitions of the variables used.

$<$ Please insert Table 2 about here>

We used two models to determine whether any changes through time in the effect of home ownership were the result of changes in the age and household composition of the population of homeowners versus renters, or to greater dynamics in the owner-occupied market. One model only contains the period effect (which has been used as a proxy for economic circumstances, labour market, and housing market conditions); housing tenure; and the interaction effect of the two. The second model also includes individual characteristics and the degree of urbanization as control variables. The differences between the two models in the period-tenure interaction gives us information about the role of population composition: a period-tenure interaction in the first model and not in the second would have to be the result of compositional change over the research period.

No variable for gender has been included in the analysis. For couple households the inclusion of gender would not make much sense, because the data do 
not allow a distinction to be drawn between reasons for moving relating directly to the circumstances of the respondent, or to the partner of the respondent. The gender effect is therefore only clearly defined for one-person households. For these, the gender effect proved to be insignificant.

Because it was not known whether one model for the research period of almost twenty years could be used without having to account for potential changes in parameters over that period, separate logistic regression models were also run for every individual Housing Demand Survey.

\section{RESULTS}

Indeed, as already mentioned in the introduction, the probability of migrating has been relatively stable over the years with only slight fluctuations (Figure 2). There is no sign whatsoever of an ongoing decrease of the percentage migrating as a result of an increase in home ownership. We may therefore conclude that at least one factor counterbalancing the expected negative effect of the growth of home ownership on migration is at work.

$<$ Please insert Figure 2 about here $>$

The impression drawn from Figure 3 is that the difference in levels of migration between homeowners and renters has remained approximately the same. Homeowners moved slightly more often to rented accomodations in 1997, perhaps taking advantage of the high house prices to release the equity from their homes (Helderman et al. 2004).

\section{$<$ Please insert Figure 3 about here $>$}

The percentage of migration by household composition, shown in Figure 4, has developed differently for different household categories. The overall picture, however, is that one-person households and childless couples are still the most frequently migrating categories, among both homeowners and renters. Both these household types also show the greatest growth in their share among homeowners (Figure 1). A further increase of these household types among homeowners might indeed lead to higher levels of migration among homeowners.

\section{< Please insert Figure 4 about here>}

The changes in migration also differ slightly by age (Figure 5). Furthermore, among homeowners, the younger age categories show a particularly strong increase in migration at the end of the research period: more than the older age categories, and also more than their renting counterparts.

$<$ Please insert Figure 5 about here $>$

Multivariate results - To check whether we could use one model for the research period of almost twenty years without having to account for potential changes in parameters over that period, separate logistic regression models were run for every 
individual Housing Demand Survey (see Appendix A). The results show that the parameters of the independent variables do not vary much over the research period and all parameters have the same sign for every period (+/-). Income turns out to be more important to migration in the period of 1984-85 than in the other periods. Only the effect of the tertiary level of education is significantly different from the primary level in the 1990s. In 1988-89, the differences between household types are less marked than in the other periods. The separate models for each period give a first impression off the effect of being a homeowner on the probability to migrate. The results show that the negative effect of being a homeowner on the probability to migrate is fairly constant over the 5 periods although the effect seems to become slightly stronger between 1988-98 and 1997-98. Although we expected the difference between owners and renters to become smaller, we might draw a first carefull conclusion that the opposite is true.

Table 3 presents two multivariate models including respondens from all five Housing Demand Surveys. Model 1 only includes the main effect for homeownership, period and the interaction between homeownership and period. As expected, the main effect for homeownership is negative, indicating that homeowners migrate much less than renters. In Model 1, the period effect is only significant and positive for 1993-94 and 1997-98, indicating an increase in the probability of migrating in these periods after accounting for housing tenure. For 1997-98 this was to be expected, given the fact that migration increased in that period even before tenure was accounted for (see Figure 2). It must be noted that the period effect for 1997-98 is probably slightly exaggerated owing to a longer observation period for Housing Demand Survey 1998.

The interaction of period and tenure only shows a negative and significant effect for 1997-98. This is the only period during which homeowners changed their behaviour significantly. In order to be able to compare the effect of being a renter and being a homeowner for the different periods, the estimates of the main and interaction effects should be interpreted together. For renters this is straightforward because the period effect for renters is the main effect of period in Model 1. For Homeowners, the main effect of being a homeowner, the main effect for period and the interaction effect between period and homeownership have to be summed. Doing this reveals that for both renters and homeowners the probability of migrating increased between 1980 and 1998, but that for renters the increase was stronger (for renters the increase in the parameters between 1980-81 and 1997-98 is 0.657 and for owners the increase is 0.351).

The overall conclusion is that homeowners clearly have a lower probability to migrate than renters in all periods. However, for both renters and homeowners the probability to migrate increases from 1993 onwards and the increase is largest for renters. So contrary to our expectations, also these results show that the differences between owners and renters seem to become larger instead of smaller. Possibly, renters took particular advantage of the new opportunities provided by the booming economy to advance their labour-market career. As shown by Wagner (1989), homeowners are less likely to change jobs than renters, probably to some extent because they have more frequently already 'settled down' in their labour market careers.

<Please insert Table 3 about here> 
In Model 2, the control variables are included. In comparison with Model 1, the main effect of tenure is even stronger, while the period effect remains almost the same. So, after controlling for other variables, renters migrated more than homeowners and migration became more likely in the period 1997-98. If the interaction effect between period and tenure as found in Model 1 had been the result of changes in the composition in the population of homeowners over time, we would expect this effect to disappear after controlling for various individual and household characteristics. The interaction between period and tenure in Model 2 is indeed closer to zero and no longer yields significant parameters. However, the effect for 1997-98 only just exceeds the ten percent confidence level (the significance level is 0.103) and the change in magnitude of the parameter is only small. Furthermore, had we chosen 1988-89 as the reference period, we would have found a significant difference between that period and 1997-98. From additional analyses (not shown), we found that it was not the inclusion of one single variable that caused the interaction effect to change, but rather the combination of many.

Again, in order to get the full picture, the estimates of the main and interaction effects should be interpreted together. Doing this gives roughly the same picture as for Model 1. For both renters and homeowners the probability of migrating increased between 1980 and 1998, but for renters the increase was stronger (for renters the increase in parameters between 1980-81 and 1997-98 is 0.686 and for owners the increase is 0.456). Based on these results, the conclusion can be drawn that home ownership is still a very strong restriction for migration, despite the arrival of younger household types among homeowners.

As expected, the probability of migrating decreases with increasing age. Also as expected, the higher the level of education, the more likely is migration to occur. Income has a similar positive effect on migration, but given the negative effect of income squared, the effect is less strong for the very high incomes. Selfemployment, unexpectedly, shows a positive effect on migration, but it is insignificant. If the multivariate analysis is run with only selfemployment, or with any combination of all other control variables except home ownership, selfemployment shows the expected negative and significant effect. The explanation is that about 76 percent of selfemployed own their homes. Dual-income households are less likely to migrate than single earners, in accordance with our expectations. Couples without children are more likely to migrate than other household types. As expected, couples with children are the least likely to migrate. The negative and significant effect of the degree of urbanization supports the notion that living in one of the most urbanised areas in the Netherlands eliminates the need for migration for some people.

\section{DISCUSSION}

This study addressed the question to what extent the growth in home ownership led to a decrease in migration in the Netherlands in the 1980s and 1990s, and to what extent the effect of home ownership on migration changed. Although one might assume that a growth in home ownership ought to lead to a decrease in migration, there was no decrease in migration in the period under study. On the contrary: migration grew in the second half of the 1990s. There were three reasons capable of explaining why the connection between the evolution of home ownership and migration might not be straightforward. First, homeowners increasingly belong to the otherwise mobile categories; the young and the childless. Second, the internal dynamics in the owner- 
occupied segment of the housing market might have intensified, because of a widening choice in this segment. Third, a positive effect of macro factors affecting migration might have offset the negative effect of an increase in home ownership. Examples of these macro factors are the economic growth at the end of the research period, accompanied by an increase in job opportunities and job mobility, a historically low housing shortage, and low mortgage interest. The results show that the growth of home ownership among younger, childless households did not lead to an increase in the migration of homeowners compared with renters. Instead, the effect of home ownership on migration became stronger at the end of the research period in the model that only accounts for housing tenure and period: homeowners became more likely to migrate, but so did renters, and to an even greater extent. After accounting for household composition, age, dual earnership, and other control variables, the change in the effect of home ownership on migration through time was reduced to a smaller and (just barely) insignificant effect. Home ownership still remained a very strong restriction for migration. The conclusion must be that the overall growth of migration in the research period was entirely owing to macro factors.

Home ownership is still growing in the Netherlands, rising to 54 percent in 2003 and expected to grow further. This growth means that there will be an increasing number of households who are generally less interested in, or capable of, migrating for the sake of a job. During the research period, economic growth and a favourable housing market probably compensated for a possible negative effect of the growth of home ownership on migration. In periods of economic and/or housing market decline, this compensation will be absent, possibly leading to a future decrease in migration. Such a decrease might also lead to a greater reliance on daily mobility if jobs elsewhere were accepted without resulting in migration. This increased mobility would lead to environmental problems and road congestion, despite the fact that road networks improved in the 1980s and 1990s, allowing people to access jobs at much greater distances without having to migrate (Forrest 1987; Van Wee 2000).

Furthermore, the results indicate that two different policy goals of the Netherlands government seem to contradict each other: a continued growth in home ownership, and a limitation of daily mobility growth would be difficult to achieve concurrently.

\section{Acknowledgements}

The Netherlands Organization for Scientific Research supported this research (NWO grant 015.000.013). We are grateful to Rinus Deurloo at the Amsterdam institute for Metropolitan and International Development Studies (AMIDSt, University of Amsterdam) and to various other colleagues for their valuable comments on earlier versions of this paper. Maarten van Ham contributed to this paper while he was a member of AMIDSt, University of Amsterdam.

\section{REFERENCES}

Bartel, A.P. (1979), The migration decision: what role does job mobility play? The American Economic Review, 69(5), pp. 775-786.

Börsch-Supan, A. (1990) Education and its double-edged impact on mobility. Economics of Education Review 9, pp. 39-53 
DaVanzo, J.S. (1981), Microeconomic approaches to studying migration decisions. In: G.F. De Jong \& R.W. Gardner, eds., Migration decision making: multidisciplinary approaches to microlevel studies in developed and developing countries, pp. 394. New York: Pergamon.

De Koning, J., G. Bijwaard, A. Gelderblom, \& H. Kroes (2003), Arbeidsmarkttransities en aanboddiscrepanties. [Labour market transitions and supply discrepancies.] Rotterdam: University of Tilburg/ Utrecht University.

Clark, W.A.V., \& F.M. Dieleman (1996), Households and housing: Choice and outcomes in the housing market. New Jersey: New Brunswick, NJ, Center for Urban Policy Research, Rutgers, The State University of New Jersey.

Feijten, P., \& C.H. Mulder (2002), The timing of household events and housing events in the Netherlands: a longitudinal perspective. Housing Studies, 17(5), pp. 773-792.

Fischer, P.A., \& G. Malmberg (2001), Settled people don't move: on life course and (im-)mobility in Sweden. International Journal of Population Geography, 7, pp. 357-371.

Forrest, R. (1987). Spatial mobility, tenure mobility, and emerging social division in the UK housing market. Environment and Planning A, 19.

Goetgeluk, R.W. (1997), Bomen over wonen: woningmarktonderzoek met beslissingsbomen [Trading off housing preferences. Housing market research with decision plan nets.] Utrecht: Utrecht University

Haapanen, M. (2003), Studies on the determinants of migration and the spatial concentration of labour. Jyväskylä: University of Jyväskylä.

Hachen, D. S. (1988), The competing risks model. A method for analyzing processes with multiple types of events. Sociological Methods \& Research, 17(1), pp. 21-54.

Hägerstrand, T., (1970), What about people in regional science? Papers of the Regional Science Association 24, pp. 7-21.

Hardill, I., A.E. Green, A.C. Dudleston \& D.W. Owen (1997), Who decides what? Decision making in dual career households. Work, employment \& Society, 11(2), pp. 313-326.

Helderman, A.C. (2004), Intergenerational transmission of homeownership. $2^{\text {nd }}$ International Conference on Population Geographies. August $11^{\text {th }}-14^{\text {th }}, 2004$.

Helderman, A.C., C.H. Mulder \& M. van Ham (2004), The changing effect of homeownership on residential mobility in the Netherlands, 1980-98. Housing Studies, 19(4), pp. 601-616.

Leijnse, F., S.H. Baljé \& P.A.J. Oomens (2001), Economie van de $21^{\text {ste }}$ eeuw: Het nieuwe werk nemen [Economics of the 21st Century: taking the new job], Ministry of Economic Affairs.

Mulder, C.H. (1993), Migration dynamics: A life course approach. Amsterdam: Thesis Publishers.

Mulder, C.H., \& P.H. Hooimeijer (1999), Residential relocations in the life course. In: L. J. G. Van Wissen \& P. A. Dykstra, eds., Population issues, an interdisciplinary focus, pp. 159-186. New York: Plenum.

Mulder, C.H., \& M. Wagner (1998), First-time home-ownership in the family life course: a West German-Dutch comparison. Urban Studies, 35(4), pp. 687-713.

Netherlands Ministry of Spatial Planning, Housing and the Environment (2002) Cijfers over wonen 2002. Feiten over mensen, wensen, wonen [Figures on 
housing 2002. Facts about people, wishes, housing]. The Hague: Netherlands Ministry of Spatial Planning, Housing and the Environment.

Roseman, C.C. (1971), Migration as a spatial and temporal process. Annals of the Association of American Geographers, 61(3), pp. 589-598.

Schutjens, V.A.J.M., R. Van Kempen \& B. Wiendels (1998), Werk-gë̈nduceerde migratie over lange afstand: een vooronderzoek. [Long distance migration for job related reasons, a preliminary study.] Utrecht: Department of Spatial Sciences, Utrecht University.

Simpson, W. (1992), Urban structure and the labour market; worker mobility, commuting, and underemployment in cities. Oxford: Clarendon.

Sjaastad, L.A. (1962), The costs and returns of human migration. The journal of political economy, 70, pp. 80-93.

Smits, J. (2001), Career migration, self-selection and the earnings of married men and women in the Netherlands, 1981-93. Urban Studies, 38(3), 541-562.

Smits, J., C.H. Mulder \& P. Hooimeijer (2003), Changing gender roles, shifting power balance and long-distance migration of couples. Urban Studies, 40(3), pp. 603-613.

Speare, A., Jr., S. Goldstein \& W.H. Frey (1975), Residential mobility, migration, and metropolitan change. Cambridge: Ballinger.

Van Ham, M., C.H. Mulder \& P.H. Hooimeijer (2001) Spatial flexibility in job mobility: macro-level opportunities and micro-level restrictions. Environment and Planning A 33, pp. 921-940

Van Ham, M. (2002), Job access, workplace mobility, and occupational achievement. Delft: Eburon.

Van Leuvensteijn, M., \& P. Koning (2000), The effects of home-ownership on labour mobility in the Netherlands: Oswald's thesis revisited (Vol. 173). Research Memorandum: CPB Netherlands Bureau for Economic Policy Analysis.

Van Ommeren, J. (1996), Commuting and relocation of jobs and residences: a search perspective. Amsterdam: Vrije Universiteit Amsterdam.

Van Ommeren, J., P. Rietveld \& P. Nijkamp (2000), Job mobility, residential mobility and commuting: a theoretical analysis using search theory. The annals of regional science, 34, pp. 213-232.

Van Wee, G.P. (2000), Verkeer, milieu en ruimte: onderzoek en beleid in beweging. [Transport, environment and space: research and policy on the move.] Utrecht: Utrecht University.

Wagner, M. (1989), Spatial determinants of social mobility: An analysis with life history data for three West German cohorts. In: J. Van Dijk \& H. Folmer \& H. W. Herzog \& A. M. Schlottman, eds., Migration and Labor Market Adjustment, pp. 241-264. Dordrecht: Kluwer Academic.

Yapa, L., M. Polese \& J. Wolpert (1971), Interdependencies of commuting, migration, and job site relocation. Economic Geography, 47(1), pp. 59-72.

List of figures:

Figure 1 Household composition of homeowners

Figure 2 Percentage migrating

Figure 3 Percentage migrating by tenure

Figure 4 Percentage migrating by household composition

Figure 5 Percentage migrating by age 
List of tables:

Table $1 \quad$ Some differences between owners and renters in 1998

Table $2 \quad$ Variable summary statistics and definitions

Table 3 Logistic regression of moving 35 kilometres or more in the two years preceding the interview

Appendix A Logistic regression of moving 35 kilometres or more in the two years preceding the interview, per Housing Demand Survey (1981-98)

Figure 1 Household composition of homeowners

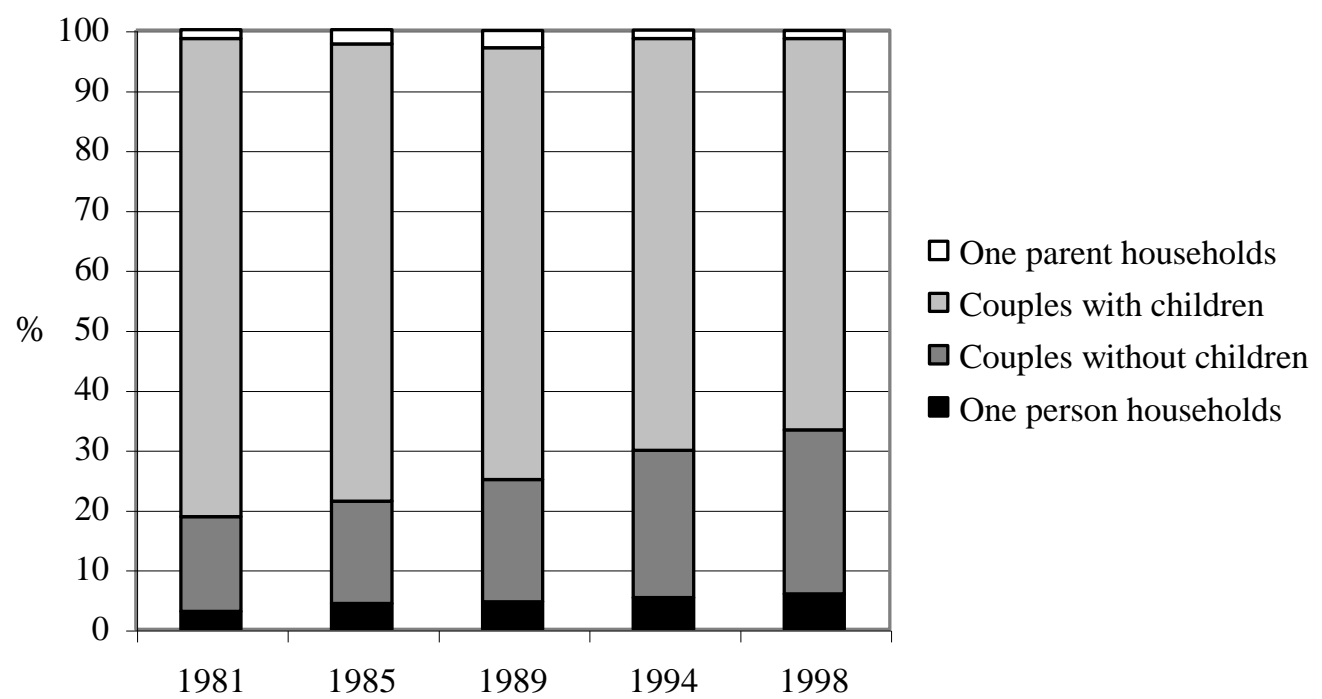

Source: Statistics Netherlands, Housing Demand Surveys 1981-1998

Figure 2 Percentage migrating

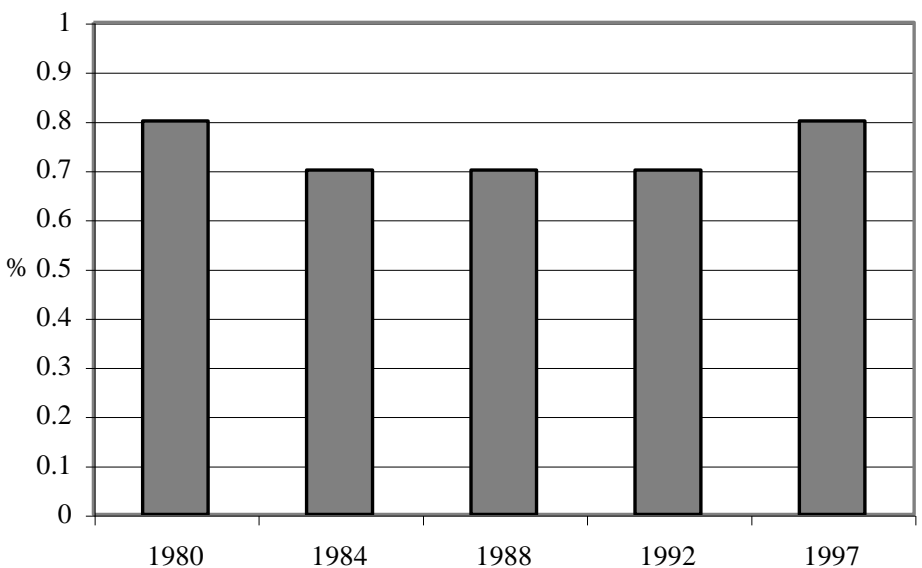

Source: Statistics Netherlands, Housing Demand Surveys 1981-1998 
Figure 3 Percentage migrating by tenure

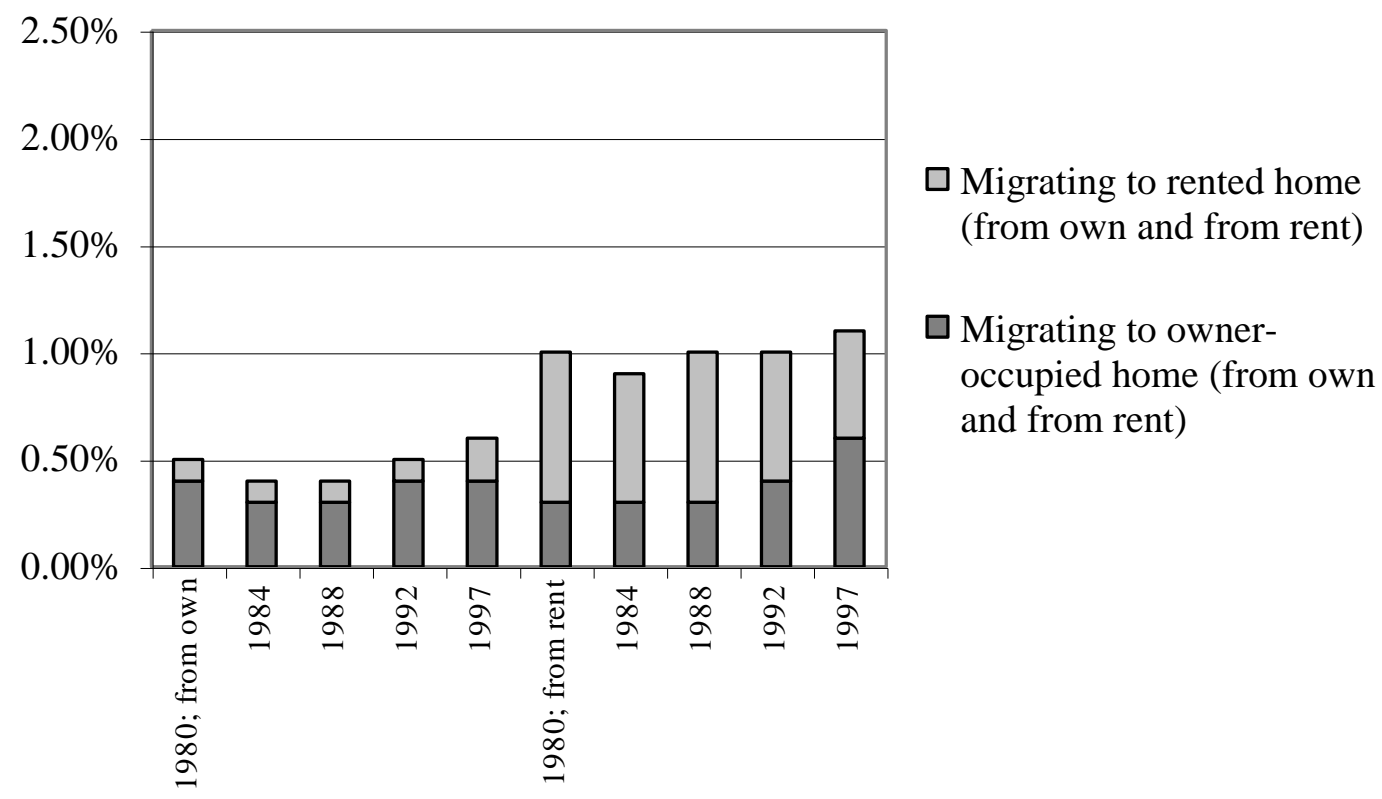

Source: Statistics Netherlands, Housing Demand Surveys 1981-98.

Figure 4 Percentage migrating by household composition

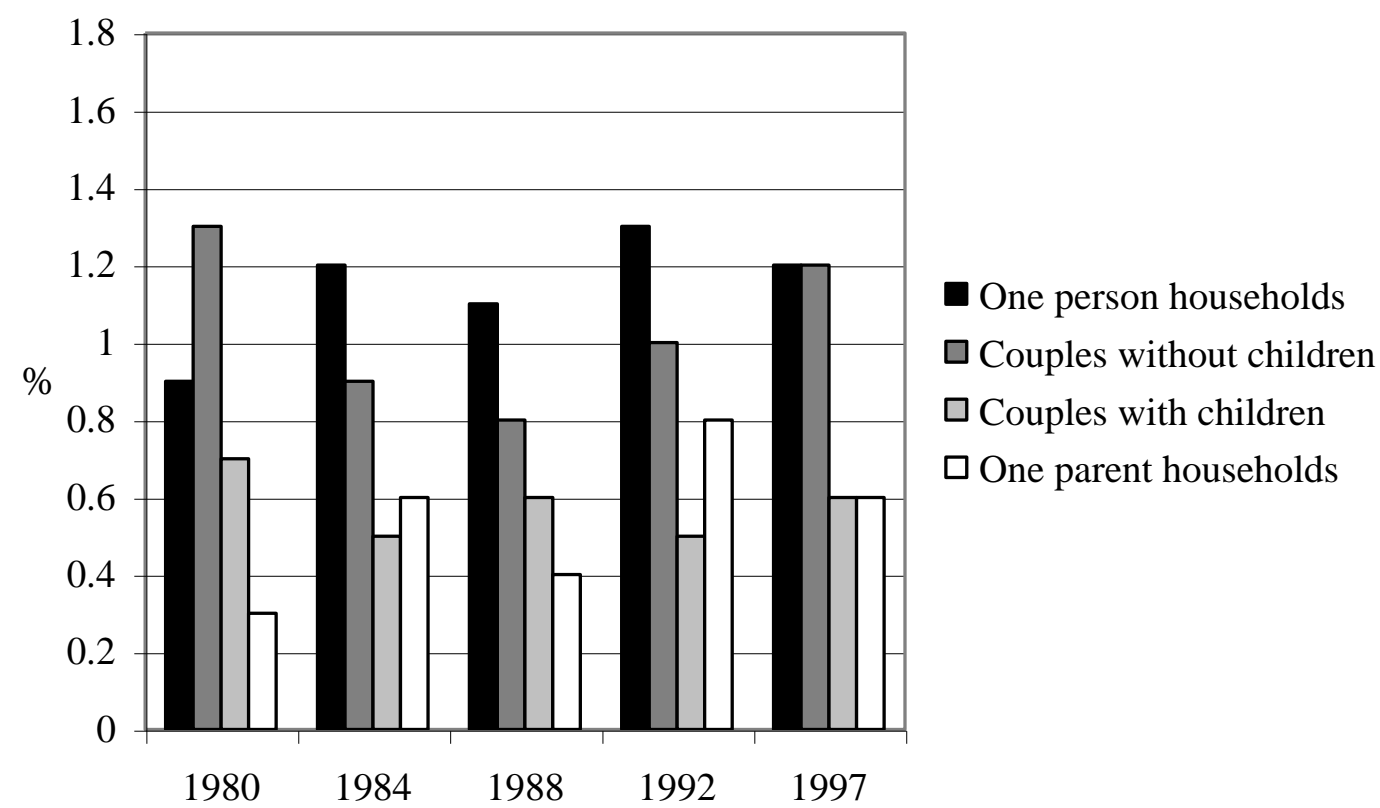

Source: Statistics Netherlands, Housing Demand Surveys 1981-98 
Figure 5 Percentage migrating by age

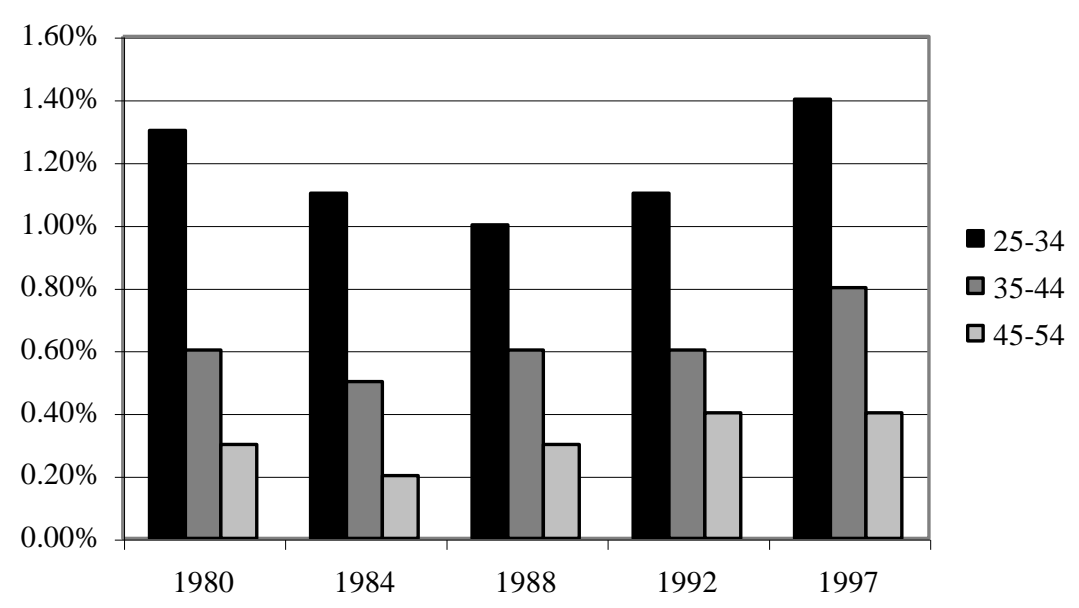

Source: Statistics Netherlands, Housing Demand Surveys 1981-98

Table $1 \quad$ Some differences between owners and renters in 1998

$\begin{array}{lllr} & \text { Dual earners } & \text { Couples with children Above } \\ \text { Homeowners } & 51.1 \% & 65.3 \% & 54.5 \% \\ \text { Renters } & 27.1 \% & 42.6 \% & 22.6 \%\end{array}$

Source: Housing Demand Survey 1998 
Table 2 Variable summary statistics and definitions

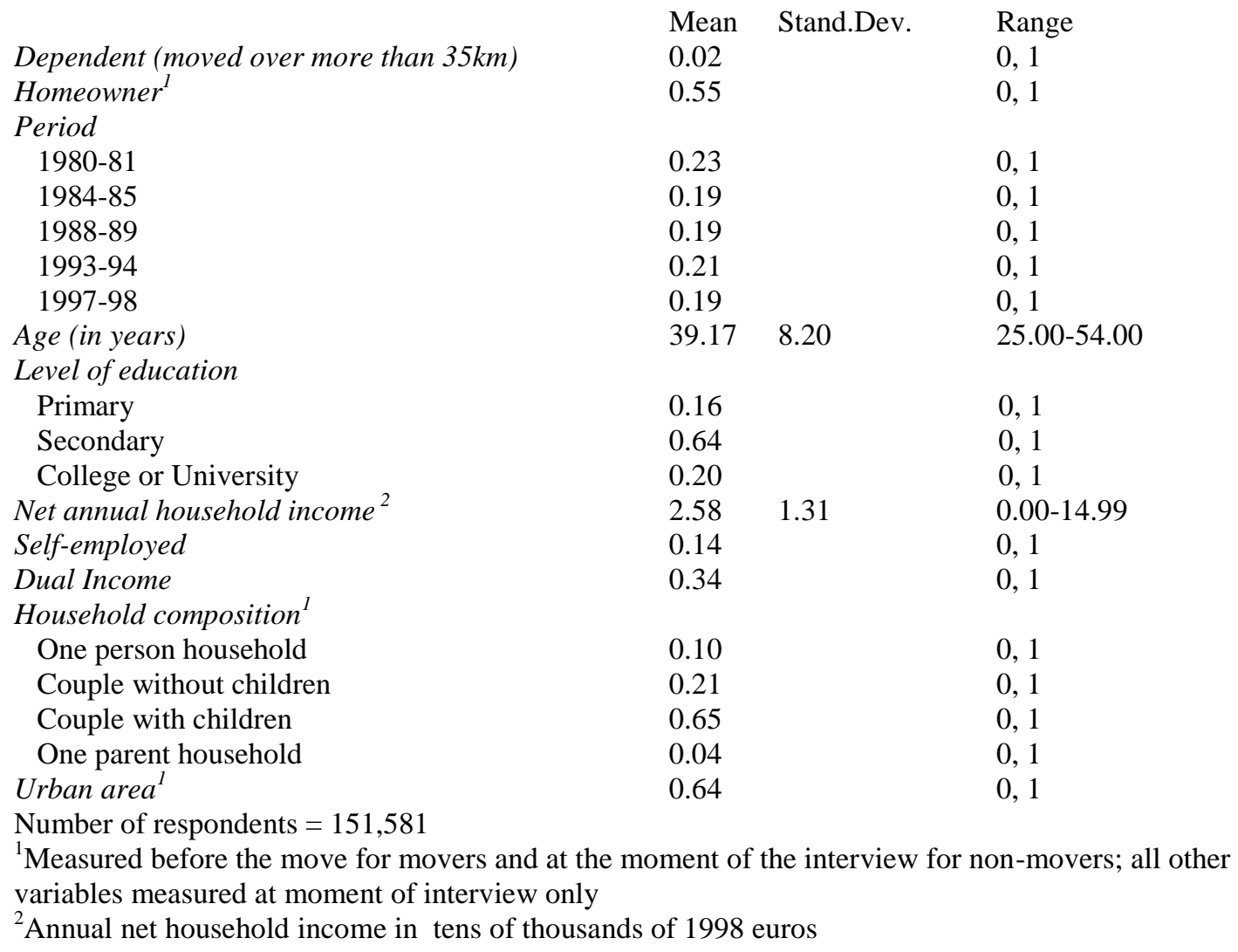

Source: Statistics Netherlands, Housing Demand Surveys 1981-98 
Table 3 Logistic regression of moving 35 kilometres or more in the two years preceding the interview

\begin{tabular}{|c|c|c|c|c|c|c|}
\hline & \multicolumn{3}{|c|}{ Model 1} & \multicolumn{3}{|c|}{ Model 2} \\
\hline & $\mathrm{B}$ & S.E. & Sig. & $\mathrm{B}$ & S.E. & Sig. \\
\hline Home ownership (ref=rent) & -0.798 & 0.107 & $* * *$ & -1.015 & 0.110 & $* * *$ \\
\hline \multicolumn{7}{|l|}{ Period $($ ref $=1980-81)$} \\
\hline $1984-85$ & 0.050 & 0.094 & & 0.098 & 0.096 & \\
\hline $1988-89$ & -0.066 & 0.099 & & -0.078 & 0.102 & \\
\hline 1993-94 & 0.173 & 0.090 & $*$ & 0.047 & 0.093 & \\
\hline $1997-98$ & 0.707 & 0.084 & $* * *$ & 0.686 & 0.089 & $* * *$ \\
\hline \multicolumn{7}{|c|}{ Interaction between period and tenure (ref $=1980-81$ by rent $)$} \\
\hline $1984-85$ by own & -0.007 & 0.158 & & 0.012 & 0.160 & \\
\hline $1988-89$ by own & 0.056 & 0.161 & & 0.175 & 0.163 & \\
\hline $1993-94$ by own & -0.056 & 0.148 & & 0.084 & 0.150 & \\
\hline $1997-98$ by own & -0.356 & 0.139 & $* *$ & -0.230 & 0.141 & \\
\hline Age (in years) & & & & -0.063 & 0.003 & $* * *$ \\
\hline \multicolumn{7}{|l|}{ Level of education ( $r e f=$ primary education) } \\
\hline Secondary education & & & & 0.398 & 0.088 & $* * *$ \\
\hline College or University & & & & 1.206 & 0.094 & $* * *$ \\
\hline Income & & & & 0.594 & 0.060 & $* * *$ \\
\hline Income squared & & & & -0.043 & 0.007 & $* * *$ \\
\hline Self Employment ( ref=not self employed) & & & & 0.111 & 0.073 & \\
\hline Dual income household (ref=no dual income hou & old) & & & -0.645 & 0.062 & $* * *$ \\
\hline \multicolumn{7}{|l|}{ Household composition (ref=one person household) } \\
\hline Couple without children & & & & 0.127 & 0.088 & $* *$ \\
\hline Couple with children & & & & -0.344 & 0.080 & $* * *$ \\
\hline One parent household & & & & 0.117 & 0.141 & \\
\hline Urban area (ref=outside most urbanised areas) & & & & -0.535 & 0.047 & $* * *$ \\
\hline Constant & -3.990 & 0.062 & $* * *$ & -2.640 & 0.178 & $* * *$ \\
\hline Initial -2 Log Likelihood & 20608 & & & 20400 & & \\
\hline Model -2 Log Likelihood & 20145 & & & 18623 & & \\
\hline Improvement & 463 & $d f=9 ; p=$ & .00 & 1777; & $\mathrm{Af}=20$ & $=0.00$ \\
\hline
\end{tabular}

$*=\mathrm{p}<0.10 ; * *=\mathrm{p}<0.05 ; * * *=\mathrm{p}<0.01$

Source: Statistics Netherlands, Housing Demand Surveys 1981-98 
Appendix A Logistic regression of moving 35 kilometres or more in the two years preceding the interview per Housing Demand Survey (198198)

Home-ownership (ref=rent)
Age
Level of education (ref=primary
education)
Secondary education
College or University
Income
Income squared
Self-employment (ref=not self-employed)
Dual income household (ref= no dual
income household)
Household composition (ref=one person
household)
Couple without chidren
Couple with children
One-parent household
Urban area (ref=outside most urban
areas)
Constant
Initial -2 Log Likelihood
Model -2 Log Likelihood
Improvement

\begin{tabular}{|c|c|c|c|c|c|c|c|c|c|c|c|c|c|c|}
\hline \multicolumn{2}{|l|}{$1980-81$} & \multicolumn{4}{|c|}{$1984-85$} & \multicolumn{2}{|l|}{ 1988-98 } & \multicolumn{4}{|c|}{ 1993-94 } & \multicolumn{3}{|l|}{$1997-98$} \\
\hline & Sig. & S.E. & B & Sig. & S.E. & B & Sig & S.E. & B & Sig & S.E. & B & Sig & S.E. \\
\hline-0.907 & $* * *$ & 0.115 & -1.106 & $* * *$ & 0.128 & -0.978 & $* * *$ & 0.134 & -1.049 & $* * *$ & 0.117 & -1.192 & $* * *$ & 0.100 \\
\hline-0.061 & $* * *$ & 0.007 & -0.062 & $* * *$ & 0.008 & -0.067 & $* * *$ & 0.009 & -0.054 & $* * *$ & 0.007 & -0.074 & $* * *$ & 0.006 \\
\hline 0.665 & $* * *$ & 0.176 & 0.578 & $* * *$ & 0.216 & 0.790 & $* *$ & 0.349 & 0.205 & & 0.253 & 0.103 & & 0.143 \\
\hline 1.199 & $* * *$ & 0.197 & 1.494 & $* * *$ & 0.233 & 1.714 & $* * *$ & 0.358 & 1.179 & $* * *$ & 0.261 & 0.818 & $* * *$ & 0.154 \\
\hline 0.375 & $* *$ & 0.152 & 1.105 & $* * *$ & 0.222 & 0.714 & $* * *$ & 0.149 & 0.961 & $* * *$ & 0.143 & 0.453 & $* * *$ & 0.108 \\
\hline-0.032 & & 0.023 & -0.103 & $* * *$ & 0.030 & -0.042 & $* * *$ & 0.016 & -0.072 & $* * *$ & 0.015 & -0.035 & $* * *$ & 0.012 \\
\hline 0.312 & $*$ & 0.165 & -0.045 & & 0.197 & -0.060 & & 0.197 & 0.297 & * & 0.154 & 0.059 & & 0.135 \\
\hline-0.582 & $* * *$ & 0.156 & -0.887 & $* * *$ & 0.158 & -0.705 & $* * *$ & 0.157 & -0.895 & $* * *$ & 0.133 & -0.441 & $* * *$ & 0.119 \\
\hline 0.070 & & 0.211 & -0.008 & & 0.240 & -0.121 & & 0.235 & 0.047 & & 0.185 & 0.285 & * & 0.159 \\
\hline-0.553 & $* * *$ & 0.194 & -0.341 & * & 0.207 & -0.201 & & 0.200 & -0.432 & $* *$ & 0.171 & -0.373 & $* *$ & 0.147 \\
\hline-0.305 & & 0.421 & -0.384 & & 0.424 & -0.422 & & 0.417 & 0.793 & $* *$ & 0.328 & 0.400 & $*$ & 0.212 \\
\hline-0.203 & $*$ & 0.107 & -0.405 & $* * *$ & 0.116 & -0.341 & $* * *$ & 0.123 & -0.240 & $* *$ & 0.104 & -1.182 & $* * *$ & 0.094 \\
\hline-2.518 & $* * *$ & 0.391 & -3.524 & $* * *$ & 0.468 & -3.335 & $* * *$ & 0.514 & -3.593 & $* * *$ & 0.410 & -0.855 & $* * *$ & 0.287 \\
\hline 4185 & & & 3378 & & & 3143 & & & 4249 & & & 5381 & & \\
\hline 3892 & & & 3088 & & & 2873 & & & 3863 & & & 4725 & & \\
\hline $293 ; \mathrm{df}=$ & $2 ; p=0.00$ & & $290 ; \mathrm{df}=$ & $12 ; p=$ & & $270 ; \mathrm{df}=$ & $2 ; p=$ & & $386 ; \mathrm{df}=$ & $2 ; p=$ & & $656 ; \mathrm{df}$ & $2 ; p=$ & \\
\hline
\end{tabular}

$*=\mathrm{p}<0.10 ; * *=\mathrm{p}<0.05 ; * * *=\mathrm{p}<0.01$

Source: Statistics Netherlands, Housing Demand Surveys 1981-98 